Review

\title{
Impact of Genomic Technologies on Chickpea Breeding Strategies
}

\author{
Pooran M. Gaur *, Aravind K. Jukanti and Rajeev K. Varshney \\ Grain Legumes Research Program, International Crops Research Institute for the Semi-Arid Tropics \\ (ICRISAT), Patancheru 502 324, Andhra Pradesh, India; E-Mails: aravindjukanti@gmail.com (A.K.J.); \\ r.k.varshney@cgiar.org (R.K.V.) \\ * Author to whom correspondence should be addressed; E-Mail: p.gaur@cgiar.org; \\ Tel.: +91-40-3071-3356; Fax: +91-40-3071-3074.
}

Received: 11 June 2012; in revised form: 10 August 2012 / Accepted: 13 August 2012 /

Published: 23 August 2012

\begin{abstract}
The major abiotic and biotic stresses that adversely affect yield of chickpea (Cicer arietinum L.) include drought, heat, fusarium wilt, ascochyta blight and pod borer. Excellent progress has been made in developing short-duration varieties with high resistance to fusarium wilt. The early maturity helps in escaping terminal drought and heat stresses and the adaptation of chickpea to short-season environments. Ascochyta blight continues to be a major challenge to chickpea productivity in areas where chickpea is exposed to cool and wet conditions. Limited variability for pod borer resistance has been a major bottleneck in the development of pod borer resistant cultivars. The use of genomics technologies in chickpea breeding programs has been limited, since available genomic resources were not adequate and limited polymorphism was observed in the cultivated chickpea for the available molecular markers. Remarkable progress has been made in the development of genetic and genomic resources in recent years and integration of genomic technologies in chickpea breeding has now started. Marker-assisted breeding is currently being used for improving drought tolerance and combining resistance to diseases. The integration of genomic technologies is expected to improve the precision and efficiency of chickpea breeding in the development of improved cultivars with enhanced resistance to abiotic and biotic stresses, better adaptation to existing and evolving agro-ecologies and traits preferred by farmers, industries and consumers.
\end{abstract}


Keywords: chickpea; genomics; molecular markers; marker assisted-selection; marker-assisted breeding

\section{Introduction}

Chickpea (Cicer arietinum L.) is second only to the common bean (Phaseolus vulgaris L.) among food legumes for production worldwide. During 2010, the global chickpea area was 12.0 million ha, production was 10.9 million MT and yield was $913 \mathrm{~kg} \mathrm{ha}^{-1}$ [1]. Chickpea is grown in over 50 countries with $90 \%$ of its area in developing countries. Southern and South-Eastern Asia accounts for $79 \%$ of the global chickpea production. India is the largest chickpea producing country, with $68 \%$ of world chickpea production. The other major chickpea producing countries include Australia, Pakistan, Turkey, Myanmar, Ethiopia, Iran, Mexico, Canada and USA. The number of chickpea importing countries has increased from 64 in 1990 to 142 in 2009 [1] suggesting increasing global demand of the chickpea.

The genus Cicer belongs to the Leguminosae family and to the sub-family Papilionoideae. Most of the Cicer species are diploids with $2 n=2 x=16$ chromosomes and a genome of about $740 \mathrm{Mb}$ [2]. There are two distinct types of chickpea, "Kabuli" (also known as macrosperma) and "Desi" (also known as microsperma) differing in their geographic distribution and different plant type. The desi types are found in central Asia and in the Indian subcontinent while the kabuli types are mostly found in the Mediterranean region. Kabuli types are usually taller and have large beige or cream seed color and "ram's head" seeds with white flowers. Desi types are generally shorter, possessing small leaflets, pods, seeds and predominantly pink-colored flowers. Kabuli chickpea seems to have evolved from the desi types [3].

Chickpea is a good and cheap source of protein for people in developing countries (especially in South Asia), who are largely vegetarian either by choice or because of economic reasons. Additionally, chickpea is rich in minerals (phosphorus, calcium, magnesium, iron and zinc), fiber, unsaturated fatty acids and $\beta$-carotene. Recently, Jukanti et al., [4] summarized the nutritional qualities and health benefits of chickpea. Chickpea also improves soil fertility by fixing atmospheric nitrogen, meeting up to $80 \%$ of its nitrogen $(\mathrm{N})$ requirement from symbiotic nitrogen fixation [5]. Chickpea returns a significant amount of residual nitrogen to the soil and adds organic matter, improving soil health and fertility. Growing interest in chickpea consumption, coupled with increased preference for vegetable-based protein has led to an increase in global demand for chickpea. Additionally, awareness of both economic (premium prices for large seeded kabuli) and other benefits of chickpea including human health, crop diversification and sustainable agriculture have increased interest among farmers in cultivating chickpea.

Conventional breeding approaches have given over 350 improved cultivars, which have contributed to improved productivity, reduced fluctuations in yield, and enhanced adaption of chickpea to new niches [6]. Remarkable progress has been made in recent years in developing novel genetic tools, such as molecular markers, genetic maps, and genome profiling techniques to identify genomic regions, quantitative trait loci (QTL) and genes governing traits of interest [7,8]. These new advances in genomics provide exciting opportunities to researchers and breeders to utilize these new technologies 
for improving and stabilizing chickpea yield for the benefit of farmers and consumers. The aim of this review is to provide an update on progress in the development and application of molecular breeding approaches to the improvement of chickpea.

\section{Breeding Methods in Chickpea}

During the early phases of chickpea improvement, selections from native or introduced landraces were used to develop varieties. Most recent varieties have been developed through hybridization. Single, three-way or multiple crosses are used, depending on the objective of the breeding program. Backcross breeding is often used to incorporate one or few traits, from a germplasm line or a wild species, into a well-adapted variety. Pedigree, bulk or different modifications of these methods are used in handling segregating generations. The pedigree method is not widely used, due to the cumbersome data collection and the fact that this approach limits the breeding program to only a few crosses [6]. A combination of bulk and pedigree methods is widely used among many chickpea breeding programs. In early segregating generations $\left(\mathrm{F}_{2}-\mathrm{F}_{3}\right)$, selection is done for simple traits (disease resistance and seed traits), since selection for yield at this stage is not very effective, due to high environment effects. Single plant selection for yield generally starts from $F_{4}$ or $F_{5}$. A method that uses early generation selection for yield for eliminating inferior crosses and inferior $\mathrm{F}_{2}$-derived families [9] is also used in some breeding programs.

There is a need to enhance precision and efficiency of selections in the segregating generations for higher and rapid genetic gains. Precision in selection for resistance/tolerance to stresses can be improved by screening under controlled environmental conditions or at hot spot locations. Genomics-assisted breeding (GAB) approaches, such as marker-assisted selection (MAS), can greatly improve precision and efficiency of selection in crop breeding [10]. Several success stories of GAB to develop superior varieties are available in temperate cereals [11] and soybean [12]. Integration of genomics tools in chickpea breeding programs has a great potential for crop improvement [13]. For instance, molecular markers can facilitate indirect selection for traits that are difficult or inconvenient to score directly (e.g., root traits, resistance to root knot nematodes), pyramiding genes from different sources (e.g., bringing together ascochyta blight resistance genes from different donors) and combining resistance to multiple stresses (e.g., resistance to fusarium wilt and ascochyta blight).

Single seed descent (SSD) and rapid generation advancement [14] methods are being used at present to reduce the time required to reach the desired level of homozygosity. Development of double-haploids is another desired approach for saving time in reaching homozygosity. There is a recent report on success in regenerating double-haploids through anther culture in chickpea [15], which opens opportunities for exploiting haploid technology in chickpea breeding programs.

The wild Cicer species are valuable gene pools, particularly for resistance to biotic and abiotic stresses $[16,17]$. These have largely remained under-utilized due to crossability barriers, but there are some examples of successful introgression of genes into the cultivated species from two closely related species, Cicer reticulatum and C. echinospermum [17]. Mutation breeding is another approach to improve a well-adapted variety for a deficient trait or creating a novel variability. Several chickpea varieties have been developed through mutation breeding [6]. 
Efficient transformation and regeneration protocols are now available for chickpea [18], which have made it possible to introduce any desired gene from any source into chickpea. Transgenic plants are being developed to improve traits which have no or limited genetic variability in the cultivated and cross-compatible wild species (primary and secondary gene pools), e.g., resistance to pod borer.

\section{Major Constraints to Chickpea Production}

The major constraints limiting chickpea production globally include various abiotic and biotic stresses. Drought is the most important constraint to yield in chickpea, accounting for about $50 \%$ yield reduction globally. It generally occurs at the terminal stage as the crop is mostly raised on conserved soil moisture under rain-fed conditions. In addition to terminal drought, heat stress at the reproductive stage has become a major constraint to chickpea production because of (1) a large shift in chickpea area from cooler long-season environments to warmer short-season environments, (2) increased area under late sown conditions, due to increased cropping intensity, and (3) an expected overall increase in temperatures due to climate change. Soil salinity is another important abiotic constraint in some chickpea growing areas of the world.

Fusarium wilt (FW), caused by Fusarium oxysporum f. sp. ciceri, dry root rot caused by Rhizoctonia bataticola, and collar rot, caused by Sclerotium rolfsi, are the important root diseases of chickpea in areas where the chickpea growing season is dry and warm, e.g., southern and eastern Asia and eastern Africa. All these diseases cause plant mortality. In general, collar rot and early- stage fusarium wilt causes mortality at the seedling stage, whereas dry root rot and late- fusarium wilt kills plants during flowering and the pod-filling stages. Ascochyta blight (AB), caused by Ascochyta rabiei (Pass.) Labr., and botrytis grey mold (BGM) caused by Botrytis cineria Pres., are the important foliar diseases of chickpea in the areas where the chickpea growing season is cool and humid. AB is important in west and central Asia, North Africa, North America, Australia, northern India and Pakistan, while BGM is important in Nepal, Bangladesh, northern India and Australia. Sources with absolute resistance (score 1 on a scale of $1-9$, where $1=$ resistant and $9=$ susceptible) to these diseases are not available in the cultivated and the wild species accessions examined so far.

Pod borer (Helicoverpa armigera Hubner) is the most important pest of chickpea worldwide. It is a highly polyphagous pest and can feed on various plant parts, such as leaves, tender shoots, flower buds, and immature seeds. The extent of global losses to chickpea by this pest is estimated at over US\$ 500 million [19]. The viral diseases, rust (Uromyces ciceris-arietini), root nematodes (Meloidogyne sp.), Phytophthora root rot (Phytophthora medicaginis), cutworm (Agrotis sp.) and leaf miner (Liriomyza cicerina) are also important in some chickpea growing areas.

\section{Breeding Achievements}

Over 350 improved varieties of chickpea have been released globally, and about half of these have been released in India, which has the largest national chickpea breeding program in the world [6]. Excellent progress has been made in the development of early maturing cultivars, which can escape terminal drought and heat stresses [20]. The first landmark variety was ICCV 2, which matures in about 85 days, and it is perhaps the world's earliest maturing variety of kabuli chickpea. It has been instrumental in extending kabuli chickpea cultivation to short-season environments of India and its 
neighboring country Myanmar. This short-duration variety covers over 50\% of the chickpea area in Myanmar [21]. Several short-duration high yielding varieties of chickpea, both in desi and kabuli types, have been developed [6,20,22]. Further advancements have been made in breeding for super-earliness in chickpea. Two super early desi chickpea lines, ICCV 96029 and ICCV 96030, were developed which mature in 75 to 80 days in southern India [23].

High root biomass has been found to be associated with drought tolerance [24-26], and a positive relationship has been established between root biomass and seed yield under drought conditions [27]. Efforts are being made to develop varieties with a vigorous and deeper root system to improve drought tolerance [28]. A large genetic variation for heat tolerance has been identified in chickpea [8,29]. A heat tolerant breeding line ICCV 92944 has been released for cultivation in Myanmar (Yezin 6) and India (JG 14). Few varieties with tolerance to moderate levels of salinity (ECe ranging from 4 to $6 \mathrm{dS} / \mathrm{m}$ ) have been developed, e.g., Karnal Chana 1 (CSG 8962) in India and Genesis 836 (ICCV 96836) in Australia [30]. Recent screening for salinity tolerance at ICRISAT identified several lines that gave a higher yield than the salinity tolerant cultivar Karnal Chana 1 under saline conditions [29,31].

Excellent progress has been made in the development of cultivars with high levels of resistance to FW, both in desi and kabuli types, because of the availability of highly resistant sources and simple and effective field screening techniques. Similar success has not been possible in breeding for resistance to ascochyta blight [32], BGM [33] and any other disease. Nevertheless, there has been a significant impact of incorporating current levels of resistance to ascochyta blight into adapted backgrounds in countries such as Australia. Development of cultivars resistant to pod borer also remained a challenge due to non-availability of sources with high levels of resistance. Higher levels of resistance were observed in some wild species [34]. Efforts are also being made to combine the non-preference (antixenosis) mechanism of resistance identified in the cultigen (e.g., ICC 506 EB) and antibiosis mechanism of resistance identified in C. reticulatum [17].

\section{Genetic and Genomic Resources in Chickpea}

\subsection{Germplasm}

The chickpea germplasm is maintained by different institutes across the world, including the International Crops Research Institute for the Semi-Arid Tropics (ICRISAT), India, and the International Centre for Agricultural Research in Dryland Areas (ICARDA), Syria (Table 1). Although a large number of cultivated and wild chickpea accessions are available, there is a large void in utilizing these accessions in breeding programs. The major limitation preventing their utilization has been lack of information on major economic traits. Additionally, screening a large number of germplasm lines in multi-location trials is both expensive and time-consuming. After evaluating about 16,990 chickpea accessions for 13 traits, a core collection of 1956 accessions has been developed at ICRISAT [35]. Further, a mini-core collection of 211 chickpea accessions has also been developed [36]. A reference set of 300 lines has been developed jointly by ICRISAT and ICARDA under the Generation Challenge Program (GCP) of the CGIAR to represent genetic variability present in the germplasm available at the two institutions [37]. The core, mini-core and reference sets of germplasm provide cost-effective and manageable entry points to initiate screening for different 
traits [38]. With the objective of trait mapping using genome-wide association studies, the reference set of chickpea is being genotyped with a large number of DArT and SNP markers and is being phenotyped for many traits both in the field and under controlled environmental conditions.

Table 1. Chickpea germplasm held at global research institutes *.

\begin{tabular}{|c|c|c|}
\hline & Institute & $\begin{array}{l}\text { Number of } \\
\text { Accessions }\end{array}$ \\
\hline 1 & $\begin{array}{l}\text { International Crops Research Institute for the Semi-Arid } \\
\text { Tropics (ICRISAT), India }\end{array}$ & 20,267 \\
\hline 2 & $\begin{array}{l}\text { National Bureau of Plant Genetics Resource (NBPGR), } \\
\text { India }\end{array}$ & 14,704 \\
\hline 3 & $\begin{array}{l}\text { International Centre for Agricultural Research in } \\
\text { Dryland Areas (ICARDA), Syrian Arab Republic }\end{array}$ & 13,462 \\
\hline 4 & Australian Temperate Field Crops Collection, Australia & 8,655 \\
\hline 5 & $\begin{array}{l}\text { Western Regional Plant Introduction Station, } \\
\text { USDA-ARS, Washington State University, USA }\end{array}$ & 6,763 \\
\hline 6 & National Plant Gene Bank of Iran, Iran & 5,700 \\
\hline 7 & Plant Genetic Resources Institute, Pakistan & 2,146 \\
\hline 8 & $\begin{array}{l}\text { N.I. Vavilov All-Russian Scientific Research Institute } \\
\text { of Plant Industry, Russian Federation }\end{array}$ & 2,091 \\
\hline 9 & Plant Genetic Resources Department, Turkey & 2,076 \\
\hline 10 & Institute of Biodiversity Conservation, Ethiopia & 1,173 \\
\hline
\end{tabular}

\subsection{Mapping Populations}

The mapping populations generally used in linkage mapping include $F_{2}, F_{2}$-derived $F_{3}$ progeny, backcrosses, doubled haploid, recombinant inbred lines (RILs) and near-isogenic lines (NILs). Some of the studies have used $F_{2}$ populations and $F_{3}$ progenies in linkage mapping of chickpea [39-41], but most of the studies have used RILs. The RIL mapping populations are of immense value in linkage mapping, as they are immortal and phenotyping can be replicated over locations and years. Several interspecific and intraspecific RIL populations are available in chickpea. The traits being targeted for mapping include resistance to $\mathrm{AB}, \mathrm{FW}$ and $\mathrm{BGM}$; root traits; salinity tolerance and protein content.

Development of a multi-parent advanced generation inter-cross (MAGIC) population is in progress at ICRISAT. This population is being developed from eight parents and includes cultivars and elite breeding lines from India and Africa. Twenty-eight two-way, 14 four-way and 7 eight-way crosses were made to develop this MAGIC population. The large number of accumulated recombination events in MAGIC populations increase novel rearrangements of alleles and bring about greater genetic diversity. MAGIC populations provide a platform for a community-based approach to gene discovery, characterization and deployment of genes for understanding complex traits [38]. In addition to trait mapping, the highly recombined MAGIC population may be used directly as source material for the development of improved cultivars. 


\subsection{Development of Molecular Markers}

Important pre-requisites for undertaking molecular breeding are molecular markers, genetic maps and markers associated with traits [42]. Isozyme markers were used for map development in chickpea during the early days of genomic studies. But, expression of these markers was influenced by the environment and their number was small, coupled with a low level of polymorphism in cultivated genotypes of chickpea. In some earlier studies, RFLP and RAPD markers were also used for genetic mapping and diversity studies [43]. However, the extensive use of molecular markers in chickpea genetics and breeding started only after development of simple sequence repeat (SSR) or microsatellite markers.

SSR markers have become the marker of choice in plant breeding due to their multi-allelic and co-dominant nature [44]. Both genomic and transcript datasets have been utilized to develop SSR markers. Several hundred SSR markers have been developed from genomic DNA libraries [45-48]. Recently, Nayak et al., [49] have developed a set of 311 novel SSR markers, designated as "ICRISAT

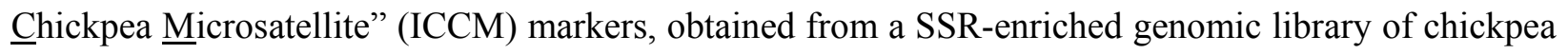
accession, ICC 4958. SSR markers have also been mined from expressed sequence tags (ESTs) [50,51]. Varshney et al., [52] have identified a total of 3728 SSR and designed primer pairs for 177 new EST-SSR markers. In another study, generating and mining of 435,018 454/FLX sequences and 21,491 Sanger ESTs produced a total of 103,215 tentative unique sequences (TUSs) [53]. The TUSs were used to identify 26,252 SSRs and primer pairs were designed for 3172 SSRs. This resulted in 728 non-redundant SSR primer pairs. Another source for developing SSR markers is BAC libraries. Lichtenzveig et al., [54] developed and characterized 233 SSRs from BAC libraries. In another study, Thudi et al., [55] obtained 6845 SSRs by mining 46,270 BESs and primer pairs that were designed for only 1344 SSRs. In summary, primer pairs are available for about 2000 SSR markers.

Single nucleotide polymorphism (SNP) markers have drawn greater attention in recent years due to their higher abundance and amenability to high-throughput approaches. About 21,405 high confidence SNPs were identified from 742 EST contigs along with several SSR and EST-SSR markers [52]. In another study by Gujaria et al., [51] a total of 1893 SNPs were identified by scanning 220 candidate genic regions in chickpea. Chickpea transcriptomic analysis identified a set of 495 SNPs from 103,215 TUSs [53]. The average frequency of SNPs (1/35.83 bp) discovered in this study was higher than previously reported by Rajesh and Muehlbauer [56], 1/61 bp in coding regions and 1/71 bp genomic regions.

Diversity arrays technology (DArT) is a high throughput genome analysis method enabling a rapid and economical approach for screening a large number of marker loci in parallel [57]. DArT technology utilizes the microarray platform to analyze DNA polymorphism. DArT markers have been used for different purposes: (i) developing high density genetic maps and (ii) studying genetic diversity in crops like barley [58], wheat [59] and pearl millet [60]. In the case of chickpea, DArT arrays comprising 15,360 DArT clones generated from 94 diverse genotypes have been developed [55]. This study showed polymorphism with a total of 5397 markers in the germplasm examined in the study. The number of polymorphic markers in intra- and inter-specific chickpea populations ranged from 35-496 and 210-906, respectively. Polymorphism information content (PIC) values obtained for chickpea were comparable to other crops, such as sorghum and cassava [61,62]. 


\subsection{Linkage Mapping}

The limited polymorphism exhibited by cultivated chickpea for the molecular markers developed in the early phase forced researchers to use interspecific crosses in linkage mapping of chickpea. The first linkage map of chickpea was developed by Gaur and Slinkard [39,40] using isozyme markers and inter-specific crosses of $C$. arietinum with $C$. reticulatum and C. echinospermum. Later, DNA-based molecular markers, such as randomly amplified polymorphic DNA (RAPD) and restriction fragment length polymorphism (RFLP) were integrated into the chickpea linkage map by Simon and Muehlbauer [43].

The RIL population of $C$. arietinum (ICC 4958) $\times$ C. reticulatum (PI 489777) has been considered as the reference mapping population and extensively used for genome mapping $[51,55,63]$. The first integrated genetic map based on this population comprised 37 inter simple sequence repeats (ISSRs), 70 amplified fragment length polymorphisms (AFLPs), 118 sequence-tagged microsatellite sites (STMSs), 96 DNA amplification finger printings (DAFs), 17 RAPDs, 3 cDNAs, 8 isozymes and 2 sequence characterized amplified regions (SCARs), covering a total distance of 2077.9 centimorgans (cM) [63]. An advanced genetic map with 521 markers, including simple sequence repeats (SSRs) and single nucleotide polymorphisms (SNPs), with an inter marker distance of $4.99 \mathrm{cM}$ spanning $2602.1 \mathrm{cM}$, was developed from the above population [49]. In this map, Nayak et al., [49] integrated 71 SNP loci, based on gene-specific primers developed by Choi et al., [64]. This effort demonstrated the power of a comparative genomics approach (Medicago truncatula/sativa and Cicer arietinum) to identify molecular tools. The genetic maps developed based on genes are also referred to as transcript maps [65]. In the case of chickpea, Gujaria et al., [51] has developed a transcript map that comprises of 300 loci (including 126 genic molecular markers [GMMs]) and spans a genomic region of $766.56 \mathrm{cM}$.

Cho et al., [66] developed the first intra-specific map of cultivated chickpea from ICCV $2 \times$ JG 62 RILs. The map was developed using 3 ISSRs, 20 RAPDs, 55 STMSs along with two phenotypic markers comprising 14 linkage groups and spanning $297.5 \mathrm{cM}$. The map was used to map genes for important morphological traits along with the double podded character. An intraspecific chickpea genome map consisting of 51 STMS, 3 inter-simple sequence repeats (ISSRs) and 12 resistance gene analogs (RGA) mapped to eight linkage groups was developed using an $F_{2}$ population of chickpea [67]. Another map developed based on a "Kabuli $\times$ Desi" cross included a total of 134 molecular markers (3 ISSR, 13 STMSs AND 118 RAPDs) mapped to 10 linkage groups [68]. This map spanned a genomic region of $534.5 \mathrm{cM}$ with an average marker interval of $8.1 \mathrm{cM}$. Radhika et al., [69] developed an integrated intraspecific map spanning a region of $739.6 \mathrm{cM}$, including 230 markers at an average distance of $3.2 \mathrm{cM}$ between markers. Another map developed recently included 144 markers assigned to 11 linkage groups, spanning $442.8 \mathrm{cM}$, with an average marker interval of $3.3 \mathrm{cM} \mathrm{[70].}$

Consensus genetic maps using both interspecific and intraspecific populations were also developed. A consensus map based on five interspecific $(C$. arietinum $\times$ C. reticulatum $)$ and five intraspecific (Desi $\times$ Kabuli types) populations was developed [71]. It integrated 555 marker loci including, RAPDs (251), STMSs (149), AFLPs (47), 33 cross-genome markers, 28 gene-specific markers, 10 isozyme markers, 10 inter-simple sequence repeats (ISSRs) and 7 RGA loci. Several other linkage maps were developed using different mapping populations with different morphological and molecular 
markers [66,67,72-74]. More recently, a comprehensive genetic map spanning $845.56 \mathrm{cM}$ was developed using RILs from C. arietinum (ICC 4958) $\times$ C. reticulatum (PI 489777) [55]. In total, it included 1291 markers on eight linkage groups (LGs). The highest number of markers per LG was on LG 3 (218) and the lowest was on LG 8 (68), with an average inter-marker distance of $0.65 \mathrm{cM}$.

In several cases, the mapping populations used for developing the maps were also phenotyped for the segregating traits. Analysis of phenotyping data together with genotyping data in some cases identified molecular markers associated with the genes/quantitative trait loci (QTLs), controlling resistance to key diseases (ascochyta blight, fusarium wilt, botrytis grey mold, rust), morphological traits (single pod vs. double pod, flowering time and flower color), seed yield and yield components, etc. (Table 2).

Table 2. List of some QTLs/genes identified for different traits in chickpea.

\begin{tabular}{|c|c|c|c|}
\hline Trait & $\begin{array}{l}\text { Number \& Name } \\
\text { of Gene/QTL }\end{array}$ & Marker & References \\
\hline \multirow[t]{5}{*}{ Ascochyta blight } & $\begin{array}{l}\text { AR2, ar1, ar1a, } \\
\text { ar1b, ar2a, ar2b, } \\
\text { Ar19 }\end{array}$ & SSRs, RAPDs, DAF & [73-77] \\
\hline & $Q T L_{A R 1}, Q T L_{A R 2}$ & $\begin{array}{l}\text { SCARs, SSRs, } \\
\text { RAPDs }\end{array}$ & {$[78,79]$} \\
\hline & 13 QTL & SSRs, RAPDs & {$[41,63,67,75,80,81]$} \\
\hline & 5 QTL (1-5) & SSRs & {$[82]$} \\
\hline & 3 QTL & SSR & [83] \\
\hline Fusarium wilt & $\begin{array}{l}\text { foc- } 0, \text { foc- } 1, \text { foc- } 2 \text {, } \\
\text { foc- } 3 \text {, foc- } 4 \text {, foc- } 5\end{array}$ & SSRs, STSs, RAPDs, & {$[63,68,75,78,84]$} \\
\hline Botrytis grey mold & 3 QTL $(1,2,3)$ & SSRs & {$[70]$} \\
\hline Rust & $1 \mathrm{QTL}$ & SSR & {$[85]$} \\
\hline Seed size traits & 2 QTL & SSRs & {$[86-88]$} \\
\hline Seed yield & $1 \mathrm{QTL}$ & SSRs & [89] \\
\hline Seed yield components & $1 \mathrm{QTL}$ & SSRs & [89] \\
\hline Single or double pod & $s$ & SSRs & {$[66,68,90]$} \\
\hline \multirow[t]{2}{*}{ Flowering time } & 2 QTL & SSRs & {$[87,91]$} \\
\hline & 2 QTL & SSRs & {$[83]$} \\
\hline $\begin{array}{l}\text { Beta carotene, leutin, } \\
\text { seed weight }\end{array}$ & $\begin{array}{l}4 \text { QTL for carotene; } \\
3 \text { QTL for seed } \\
\text { weight }\end{array}$ & SSRs & {$[92]$} \\
\hline Flower color & $B / b$ & SSR & {$[68]$} \\
\hline
\end{tabular}




\subsection{Physical Mapping}

Several genetic linkage maps have been developed and markers linked to different traits have been identified in chickpea. Though these markers can be used in marker-assisted selection (MAS) for improving the trait, the molecular basis of traits remains unknown. Isolation and validation of genes underlying the QTL/genes for the traits of interest is an essential step to determine gene function. Development of a genome-wide physical map or local physical map around the QTL region and then sequencing those region(s) are the next steps in this direction. Large-insert arrayed DNA libraries, like BAC and plant transformation competent binary BAC libraries, are essential resources for developing the physical map. Large-insert BAC libraries representing several-fold coverage of the genome have been developed in several crops. In the case of chickpea, a BIBAC library consisting of 23,780 clones, with an average insert size of $100 \mathrm{~kb}$ and covering about $3.8 \mathrm{X}$ genomes of chickpea was developed [93]. However, multi-enzyme BAC libraries with higher genome coverage are required for comprehensive genome research [94-96]. Subsequently, Lichtenzveig et al., [54] developed a BAC and BIBAC library in chickpea from the Hadas genotype; digested with HindIII and BamHI enzymes, respectively. These BAC and BIBAC libraries consist of 14,796 and 23,040 clones, respectively, with an average insert size of $121 \mathrm{~kb}$ (BAC) and $145 \mathrm{~kb}$ (BIBAC). These libraries jointly represent about 7.0X genome coverage of chickpea. Furthermore, Zhang et al., [97] constructed BAC and BIBAC libraries consisting of 22,272 and 38,400 clones, respectively. Analysis of random clones showed combined genome coverage of $11.5 \mathrm{X}$. Very recently, a BAC-library was developed from ICC 4958 that comprise 55,680 clones digested with HindIII [55]. Sequencing of 25,000 clones has provided 46,270 BAC-end sequences (BESs) that were used to develop SSR markers. SSR markers (157), derived from BESs, have been integrated into the genetic map based on the ICC $4958 \times$ PI 489777 population.

In terms of physical mapping, Zhang et al., [97] developed a BAC/BIBAC-based physical map of chickpea. It consists of 1945 contigs and each contig contains an average of 28.3 clones and has an average physical length of $559 \mathrm{~kb}$. In total, the contigs span about $1088 \mathrm{Mb}$. Using this map, they were able to identify BAC/BIBAC contigs containing or close to QTL, governing resistance to Didymella rabiei and QTL - responsible for days to first flower.

A pioneer work towards integration of genetic- and chromosome-based physical maps has been done recently by Zatloukalová et al., [98]. They have been able to assign linkage groups (LG) in chickpea to different chromosomes using flow cytometry and PCR-based primers that amplify sequence-tagged microsatellite site markers. Using this approach, they were able to assign LGs: LG8 to chromosome H, LG5 to chromosome A, LG4 to chromosome E and LG3 to chromosome B. The two chromosomes (C \& D) could not be sorted out; therefore, they were jointly assigned to LG6 and LG7. Similarly, LG1 and LG2 were assigned to chromosomes F and G. This ability to isolate individual chromosomes will be useful in high-throughput physical mapping. This could also be used to discover genes and determine the order of low-copy genic regions on a chromosome as was done in wheat $[99,100]$ and barley $[101,102]$. 


\section{Integration of Genomic Technologies in Chickpea Breeding}

Recent progress in the development of molecular markers and molecular mapping of QTL/genes of interest has made it possible to initiate genomics-assisted breeding in chickpea.

\subsection{Marker-Assisted Backcrossing (MABC)}

MABC is a backcross-based, simple molecular breeding approach being used to incorporate desirable major genes/QTL from an agronomically inferior source (donor parent) into an elite cultivar or breeding line (the recurrent parent) without any linkage drag from the donor parent [52,103-105]. Two types of selection are common, foreground and background selection. Foreground selection (FS) involves the use of two flanking markers for selecting a particular gene or a QTL [106]. Background selection (BS) uses markers that are not associated with the desirable QTL/gene and selects backcross progeny with the highest proportion of the genome of the recurrent parent $[106,107]$. The major advantages of MABC in comparison to conventional breeding include: (i) the FS can be used for selecting heterozygous plants at the seedling stage itself, (ii) recessive alleles can be identified, (iii) MABC can be used to develop near-isogenic lines (NILs) which are often used for genomic analysis, and (iv) linkage drag can be reduced [107-110].

ICRISAT, together with its partners, has initiated use of MABC in chickpea for improving drought tolerance and disease resistance. A genomic region harboring several QTL for root-related traits, harvest index, yield and yield contributing traits was located on LG4 from two intra-specific RIL mapping populations (ICC $4958 \times$ ICC 1882 and ICC $283 \times$ ICC 8261) at ICRISAT. This genomic region is being introgressed in one desi chickpea cultivar (JG 11) from ICC 4958 (desi type) and in two kabuli chickpea cultivars (KAK 2 and Chefe) from ICC 8261 (kabuli type) using MABC. The $\mathrm{BC}_{3} \mathrm{~F}_{4}$ lines were evaluated during the 2011-12 crop season in replicated yield trials at multiple locations in India, Ethiopia and Kenya. Similarly, MABC for developing chickpea breeding lines with combined resistance to FW and AB has been initiated at ICRISAT, along with research partners in India.

\subsection{Introgression of Superior Alleles from Wild Species}

Wild species/relatives of several important crop species are the reservoirs for resistance genes to different kinds of abiotic and biotic stresses. However, there has been limited use of these sources of resistance, mainly due to the transfer of associated undesirable alleles (linkage drag). But, with rapid advancements in genomics, such as genome-wide molecular markers and genetic maps and integrative QTL analysis, it is now possible to transfer the favorable alleles into an elite germplasm more efficiently. Therefore, wild species can play a major role in varietal development by being good sources of resistance/tolerance to biotic and abiotic stresses that can be used in breeding programs [111].

Several approaches have been used for introgression of genes from wild species, including introgression libraries and advanced-backcross QTL. Successive backcrossing to the recurrent parent: usually three to four generations generates introgression lines (ILs) that make up the introgression libraries. Molecular markers are used to monitor the introgressed fragments [13]. The whole donor 
genome is represented by a set of small, contiguous overlapping fragments. Such introgression lines (ILs) have been utilized in rice [112-114], tomato [115,116], soybean [117] and groundnut [118].

The advanced backcross QTL (AB-QTL) approach was proposed by Tanksley and Nelson [119]. AB-QTL detects additive, dominant, partially dominant and over-dominant QTL. The approach uses repeated backcrossing with the elite parent. Both phenotyping and genotyping (with polymorphic markers) is done on the segregating $\mathrm{BC}_{2} \mathrm{~F}_{2}$ or $\mathrm{BC}_{2} \mathrm{~F}_{3}$ population generated during backcrossing, followed by QTL analysis. This approach results in simultaneous discovery of QTL and development of introgression lines requiring only a few additional generations to develop NILs and varietal development [13]. The AB-QTL approach has been extensively used in vegetable and field crops species, like tomato [119], rice [120], wheat [121], common bean [122] and soybean [105,123]. In the case of chickpea, some efforts have also been initiated at ICRISAT to undertake AB-QTL analysis.

\subsection{Marker-Assisted Recurrent Selection (MARS)}

Plant breeders have traditionally and routinely used various recurrent selection methods to accumulate favorable alleles for yield and other polygenic traits in cross-pollinated crops. Recurrent selection involves alternating generations of selection and interbreeding to identify favorable genetic recombinations. MARS is a novel approach in which individuals for intercrossing are selected using a selection index - constructed, based on QTL-associated molecular markers [13,105,124-127]. The gain from selection using such an index is expected to be higher than phenotypic selection used in conventional recurrent selection methods [128]. QTL information is generated on the populations of interest (good-by-good crosses, in opposition to good-by-bad crosses used for QTL discovery) and QTL effects for polygenic traits (usually minor) are identified that are specific to that population. If one of the two parents presents a large QTL (such as for a quality trait or biotic stress resistance), such a QTL can also be included in the selection and the favorable allele fixed at early stages of recombination. Superior lines are developed by accumulating favorable alleles through successive intercrossing using only genotypic selection. Several factors are responsible for the effectiveness of the MARS approach, including number and size of the families, population type and reliability of marker-trait associations [129]. Knowledge of the number of minor QTL associated with the trait is directly correlated with response to MARS [13,130]. ICRISAT has initiated the use of MARS in breeding chickpea for drought tolerance. Although the utility of MARS is yet to be demonstrated in chickpea breeding, it could be useful in pyramiding genes involved in complex traits, like drought.

\subsection{Genome Wide Selection (GWS)}

GWS or genomic selection (GS), an approach based on genome-wide marker profiling, has been proposed (in addition to MARS) for improving complex traits governed by many genes/QTL. In this approach, both phenotyping and genotyping data are used to predict genomic estimated breeding values (GEBVs) of progenies. GEBVs are the sum of the effects of all QTL across the genome, exploiting all the genetic variation for a particular trait. Superior progeny lines are selected, based on the GEBVs for advancement in the breeding cycle [131-134]. Best Linear Unbiased Prediction (BLUP) and geostatistical mixed models have been developed to calculate GEBVs $[135,136]$. 
The interesting fact about GWS is that there is no need to work out marker-trait association as required in MABC or MARS [127,137,138]. Mayor and Bernardo (2009) have shown that double haploid (DH) populations are very useful in GWS compared to $F_{2}$ populations, especially for complex traits that are controlled by many QTL. Though there is little information available on the use of GWS in crop plants, it is now possible to generate genome-wide marker data (using SNPs) to start GWS in breeding programs of crops like chickpea.

\section{Concluding Remarks}

Significant progress has been made in the development of genetic and genomic resources for chickpea during the past decade. The availability of a large number of molecular markers, dense genetic maps, and markers associated with traits and transcriptomics resources, have made it possible to integrate genomics technologies into chickpea improvement. It is expected that the whole genome sequence of chickpea will be available soon. Some of the marker-assisted breeding methods, like MABC and MARS, are currently being integrated in chickpea breeding programs. Genome-wide selection is expected to be initiated soon. The integration of genomic technologies in chickpea breeding will greatly improve the efficiency of breeding programs in the development of better cultivars and reduce the time required for cultivar development.

\section{References}

1. FAOSTAT. Available online: http://faostat.fao.org/site/567/DesktopDefault.aspx (accessed on 10 January 2012).

2. Arumuganathan, K.; Earle, E.D. Nuclear DNA content of some important plant species. Plant. Mol. Biol. Report. 1991, 9, 208-218.

3. Moreno, M.; Cubero, J.I. Variation in Cicer arietinum L. Euphytica 1978, 27, 465-485.

4. Jukanti, A.K.; Gaur, P.M.; Gowda, C.L.L.; Chibbar, R.N. Nutritional quality and health benefits of chickpea (Cicer arietinum L.): A review. Br. J. Nutr. 2012, 108, S12-S26.

5. Saraf, C.S.; Rupela, O.P.; Hegde, D.M.; Yadav, R.L.; Shivkumar, B.G.; Bhattarai, S.; Razzaque, M.A.; Sattar, M.A. Biological Nitrogen Fixation and Residual Effects of Winter Grain Legumes in Rice and Wheat Cropping Systems of the Indo-Gangetic Plain. In Residual Effects of Legumes in Rice and wheat Cropping Systems of the Indo-Gangetic Plain; Kumar Rao, J.V.D.K., Johansen, C., Rego, T.J., Eds.; Oxford and IBH Publishing Co. Pvt. Ltd: New Delhi, India, 1998; pp. 14-30.

6. Gaur, P.M.; Gowda, C.L.L.; Knights, E.J.; Warkentin, T.O.; Acikgoz, N.; Yadav, S.S.; Kumar, J. Breeding Achievements. In Chickpea Breeding and Management; Yadav, S.S., Redden, B., Chen, W., Sharma, B., Eds.; CABI: Wallingford, UK, 2007; pp. 391-416.

7. Varshney, R.K.; Close, T.J.; Singh, N.K.; Hoisington, D.A.; Cook, D.R. Orphan legume crops enter the genomics era! Curr. Opin. Plant Biol. 2009, 12, 1-9.

8. Upadhyaya, H.D.; Thudi, M.; Dronavalli, N.; Gujaria, N.; Singh, S.; Sharma, S.; Varshney, R.K. Genomic tools and germplasm diversity for chickpea improvement. Plant Gen. Res. Char. Util. 2011, 9, 45-48. 
9. Slinkard, A.E.; Soth, M.B.; Vandenberg, A. Breeding for Yield: The Direct Approach. In Linking Research and Marketing Opportunities for Pulses in the 21st Century; Knight, R., Ed.; Kluwer Academic: Dordrecht, The Netherlands, 2000; pp. 1183-1190.

10. Varshney, R.K.; Graner, A.; Sorrells, M.E. Genomics-assisted breeding for crop improvement. Trends Plant Sci. 2005, 10, 621-630.

11. Varshney, R.K.; Hoisington, D.A.; Tyagi, A.K. Advances in cereal genomics and applications in crop breeding. Trends Biotechnol. 2006, 25, 1.

12. Varshney, R.K.; Thudi, M.; May, G.D.; Jackson, S.A. Legume Genomics and Breeding. Plant Breed. Rev. 2010, 33, 257-304.

13. Chamarthi, S.K.; Kumar, A.; Vuong, T.D.; Gaur, P.M.; Blair, M.W.; Nguyen, H.T.; Varshney, R.K. (2011) Trait mapping and molecular breeding. In Biology and Breeding of Food Legumes; Aditya, P., Jitendra, K., Eds.; CABI: Wallingford, UK, 2011; pp. 296-313.

14. Gaur, P.M.; Srinivasan, S.; Gowda, C.L.L.; Rao, B.V. Rapid generation advancement in chickpea. J. SAT Agric. Res. 2007, 3, 1.

15. Grewal, R.K.; Lulsdorf, M.; Croser, J.; Ochatt, S.; Vandenberg, A.; Warkentin, T.D. Doubled-haploid production in chickpea (Cicer arietinum L.): Role of stress treatments. Plant Cell Rep. 2009, 28, 1289-1299.

16. Ahmad, F.; Gaur, P.M.; Croser, J. Chickpea (Cicer arietinum L.). In Grain Legumes, Genetic Resources, Chromosome Engineering, and Crop Improvement; Singh, R.J., Jauhar, P.P., Eds.; CRC Press: Boca Raton, FL, USA, 2005; Volume 1, pp. 187-217.

17. Gaur, P.M.; Mallikarjuna, N.; Knights, T.; Beebe, S.; Debouck, D.; Mejía, A.; Malhotra, R.S.; Imtiaz, M.; Sarker, A.; Tripathi, S.; et al. Gene Introgression in Grain Legumes. In Grain Legumes: Genetic Improvement, Management and Trade; Gupta, S., Ali, M., Singh, B.B., Eds.; Indian Society of Pulses Research and Development: IIPR, Kanpur, India, 2010; pp. 1-17.

18. Jayanand, B.; Sudarsanam, G.; Sharma, K.K. An efficient protocol for the regeneration of whole plants of chickpea (Cicer arietinum L.) by using axillary meristem explants derived from in vitro germinated seedlings. In Vitro Cell. Dev. Biol. Plant 2003, 39, 171-179.

19. Ryan, J.G. A Global Perspective on Pigeonpea And Chickpea Sustainable Production Systems: Present Status and Future Potential. In Recent Advantages in Pulses Research; Asthana, A.N., Ali, M., Eds.; Indian Society of Pulses Research and Development: IIPR, Kanpur, India, 1997; pp. 1-31.

20. Gaur, P.M.; Kumar, J.; Gowda, C.L.L.; Pande, S.; Siddique, K.H.M.; Khan, T.N.; Warkentin, T.O.; Chaturvedi, S.K.; Than, A.M.; Ketema, D. Breeding Chickpea for Early Phenology: Perspectives, Progress and Prospects. In Food Legumes for Nutritional Security and Sustainable Agriculture, Proceedings of Fourth International Food legumes Research Conference; Kharkwal, M.C., Ed.; IARI, New Delhi, India, 18-22 October 2005.

21. Than, A.M.; Maw, J.B.; Aung, T.; Gaur, P.M.; Gowda, C.L.L. Development and adoption of improved chickpea varieties in Myanmar. J. SAT Agric. Res. 2007, 5, 1-3. 
22. Gaur, P.M.; Tripathi, S.; Gowda, C.L.L.; Pande, S.; Sharma, H.C.; Sharma, K.K.; Kashiwagi, J.; Vadez, V.; Krishnamurthy, L.; Varshney, R.K.; et al. International Efforts in Chickpea Improvement. In Legumes for Ecological Sustainability: Emerging Challenges and Opportunities; Ali, M., Gupta, S., Basu, P.S., Niamuddin, G., Eds.; Indian Society of Pulses Research and Development: Kanpur, India, 2009; pp. 359-377.

23. Kumar, J.; Rao, B.V. Super early chickpea developed at ICRISAT Asia Centre. Int. Chickpea Pigeonpea Newsl. 1996, 3, 17-18.

24. Saxena, N.P.; Krishnamurthy, L.; Johansen, C. Registration of a drought-resistant chickpea germplasm. Crop Sci. 1993, 33, 1424.

25. Krishnamurthy, L.; Ito, O.; Johansen, C. Genotypic Differences in Root Growth Dynamics and its Implications for Drought Resistance in Chickpea. In Dynamics of Roots and Nitrogen in Cropping Systems of the Semi-Arid Tropics; JIRCAS Agriculture Series No. 3; Ito, O., Johansen, C., Adu Gyamfi, J.J., Katayama, K., Kumar Rao, J.V.D.K., Rego, T.J., Eds.; Japan International Research Center for Agriculture Sciences: Tsukuba, Japan, 1996; pp. 235-250.

26. Ali, M.Y.; Johansen, C.; Krishnamurthy, L.; Hamid, A. Genotypic variation in root systems of chickpea (Cicer arietinum L.) across environments. J. Agron. Crop Sci. 2005, 191, 464-472.

27. Kashiwagi, J.; Krishnamurthy, L.; Crouch, J.H.; Serraj, R. Variability of root length density and its contribution to seed yield in chickpea (Cicer arietinum $\mathrm{L}$ ) under terminal drought stress. Field Crops Res. 2006, 95, 171-181.

28. Gaur, P.M.; Krishnamurthy, L.; Kashiwagi, J. Improving drought-avoidance root traits in chickpea (Cicer arietinum L.): Current status of research at ICRISAT. Plant Prod. Sci. 2008, 11, 3-11.

29. Krishnamurthy, L.; Gaur, P.M.; Basu, P.S.; Chaturvedi, S.K.; Tripathi, S.; Vadez, V.; Rathore, A.; Varshney, R.K.; Gowda, C.L.L. Large genetic variation for heat tolerance in the reference collection of chickpea (Cicer arietinum L.) germplasm. Plant Genet. Res. 2011, 9, 59-69.

30. Maliro, M.F.A.; McNeil, D.; Kollmorgen, J.; Pittock, C.; Redden, R. Screening Chickpea (Cicer arietinum L.) and Wild Relatives Germplasm from Diverse Country Sources for Salt Tolerance. In Proceedings of the International Crop Science Congress; Brisbane, Australia, 26 September1 October 2004.

31. Vadez, V.; Krishnamurthy, L.; Serraj, R.; Gaur, P.M.; Upadhyaya, H.D.; Hoisington, D.A.; Varshney, R.K.; Turner, N.C.; Siddique, K.H.M. Large variation in salinity tolerance in chickpea is explained by differences in sensitivity at the reproductive stage. Field Crops Res. 2007, 104, 123-129.

32. Pande, S.; Siddique, K.H.M.; Kishore, G.K.; Bayaa, B.; Gaur, P.M.; Gowda, C.L.L.; Bretag, T.W.; Crouch, J.H. Ascochyta blight of chickpea (Cicer arietinum L.): A review of biology pathogenicity and disease management. Aust. J. Agric. Res. 2005, 56, 317-332.

33. Pande, S.; Galloway, J.; Gaur, P.M.; Siddique, K.H.M.; Tripathi, H.S.; Taylor, P.; MacLeod, M.W.J.; Basandrai, A.K.; Bakr, A.; Joshi, S.; Krishna Kishore, G.; Isenegger, D.A.; Narayana Rao, J.; Sharma, M. Botrytis grey mould of chickpea: A review of biology, epidemiology, and disease management. Aust. J. Agric. Res. 2006, 57, 1137-1150. 
34. Sharma, H.C.; Pampapathy, G.; Lanka, S.K.; Ridsdill-Smith, T.J. Antibiosis mechanism of resistance to pod borer, Helicoverpa armigera in wild relatives of chickpea. Euphytica 2005, 142, $107-117$.

35. Upadhyaya, H.D.; Bramel, P.J.; Singh, S. Development of a chickpea core subset using geographic distribution and quantitative traits. Crop Sci. 2001, 41, 206-210.

36. Upadhyaya, H.D.; Ortiz, R. A mini core subset for capturing diversity and promoting utilization of chickpea genetic resources. Theor. Appl. Genet. 2001, 102, 1292-1298.

37. Upadhyaya, H.D.; Dwivedi, S.L.; Baum, M.; Varshney, R.K.; Udupa, S.M.; Gowda, C.L.L.; Hoisington, D.; Singh, S. Genetic structure, diversity, and allelic richness in composite collection and reference set in chickpea (Cicer arietinum L.). BMC Plant Biol. 2008, 8, 106.

38. Glaszmann, J.C.; Kilian, B.; Upadhyaya, H.D.; Varshney, R.K. Accessing genetic diversity for crop improvement. Curr. Opin. Plant Biol. 2010, 13, 1-7.

39. Gaur, P.M.; Slinkard, A.E. Genetic control and linkage relations of additional isozymes markers in chickpea. Theor. Appl. Genet. 1990a, 80, 648-653.

40. Gaur, P.M.; Slinkard, A.E. Inheritance and linkage of isozyme coding genes in chickpea. $J$. Hered. 1990b, 81, 455-459.

41. Kottapalli, P.; Gaur, P.M.; Katiyar, S.K.; Crouch, J.H.; Buhariwalla, H.K.; Pande, S.; Gali, K.K. Mapping and validation of QTLs for resistance to an Indian isolate of ascochyta blight pathogen in chickpea. Euphytica 2009, 165, 79-88.

42. Varshney, R.K.; Hoisington, D.A.; Upadhyaya, H.D.; Gaur, P.M.; Nigam, S.N.; Saxena, K.B.; Vadez, V.; Sethy, N.K.; Bhatia, S.; Aruna, R.; Gowda, M.V.C.; Singh, N. Molecular Genetics and Breeding of Grain Legume Crops for the Semi-Arid Tropics. In Genomics Assisted Crop Improvement, Genomics Applications in Crops; Varshney, R.K., Tuberosa, R., Eds.; Springer: Dordrecht, the Netherlands, 2007; Volume II, pp. 207-242.

43. Simon, C.J.; Muehlbauer, F.J. Construction of a chickpea linkage map and its comparison with maps of pea and lentil. J. Hered. 1997, 88, 115-119.

44. Gupta, P.K.; Varshney, R.K. The development and use of microsatellite markers for genetics and plant breeding with emphasis on bread wheat. Euphytica 2000, 113, 163-185.

45. Hüttel, B.; Winter, P.; Weising, K.; Choumane, W.; Weigand, F.; Kahl, G. Sequence-tagged microsatellite site markers for chickpea (Cicer arietinum L.). Genome 1999, 42, 210-217.

46. Winter, P.; Pfaff, T.; Udupa, S.M.; Sharma, P.C.; Sahi, S.; Arreguin-Espinoza, R.; Weigand, F.; Muehlbauer, F.J.; Kahl, G. Characterization and mapping of sequence-tagged microsatellite sites in the chickpea (C. arietinum L.) genome. Mol. Gen. Genet. 1999, 262, 90-101.

47. Sethy, N.K.; Choudhary, S.; Shokeen, B.; Bhatia, S. Identification of microsatellite markers from Cicer reticulatum: Molecular variation and phylogenetic analysis. Theor. Appl. Genet. 2006, 112, 347-357.

48. Sethy, N.K.; Shokeen, B.; Edwards, K.J.; Bhatia, S. Development of microsatellite markers and analysis of intraspecific genetic variability in chickpea (Cicer arietinum L.). Theor. Appl. Genet. 2006, 112, 1416-1428. 
49. Nayak, S.N.; Zhu, H.; Varghese, N.; Datta, S.; Choi, H.-K.; Horres, R.; Jüngling, R.; Singh, J.; Kavi Kishor, P.B.; Sivaramakrishnan, S.; et al. Integration of novel SSR and gene-based SNP marker loci in the chickpea genetic map and establishment of new anchor points with Medicago truncatula genome. Theor. Appl. Genet. 2010, 120, 1415-1441.

50. Varshney, R.K.; Graner, A.; Sorrells, M.E. Genic microsatellite markers in plants: Features and applications. Trends Biotechnol. 2005, 23, 48-55.

51. Gujaria, N.; Kumar, A.; Dauthal, P.; Dubey, A.; Hiremath, P.; Bhanu Prakash, A.; Farmer, A.; Bhide, M.; Shah, T.; Gaur, P.M.; et al. Development and use of genic molecular markers (GMMs) for construction of a transcript map of chickpea (Cicer arietinum L.). Theor. Appl. Genet. 2011, 122, 1577-1589.

52. Varshney, R.K.; Hiremath, P.J.; Lekha, P.; Kashiwagi, J.; Balaji, J.; Deokar, A.A.; Vadez, V.; Xiao, Y.; Srinivasan, R.; Gaur, P.M.; et al. A comprehensive resource of drought- and salinity- responsive ESTs for gene discovery and marker development in chickpea (Cicer arietinum L.). BMC Genomics 2009, 10, 523.

53. Hiremath, P.J.; Farmer, A.; Cannon, S.B.; Woodward, J.; Kudapa, H.; Tuteja, R.; Kumar, A.; Bhanu Prakash, A.; Mulaosmanovic, B.; Gujaria, N.; et al. Large-scale transcriptome analysis in chickpea (Cicer arietinum L.), an orphan legume crop of the semi-arid tropics of Asia and Africa. Plant Biotechnol. J. 2011, 9, 922-931.

54. Lichtenzveig, J.; Scheuring, C.; Dodge, J.; Abbo, S.; Zhang, H.-B. Construction of BAC and BIBAC libraries and their applications for generation of SSR markers for genome analysis of chickpea, (Cicer arietinum L.) Theor. Appl. Genet. 2005, 110, 492-510.

55. Thudi, M.; Bohra, A.; Nayak, S.N.; Varghese, N.; Shah, T.M.; Penmetsa, R.V.; Thirunavukkarasu, N.; Gudipati, S.; Gaur, P.M.; Kulwal, P.L.; et al. Novel SSR markers from BAC-end sequences, DArT arrays and a comprehensive genetic map with 1,291 marker Loci for chickpea (Cicer arietinum L.). PLoS One 2011, 6, e27275.

56. Rajesh, P.N.; Muehlbauer, F.J. Discovery and detection of single nucleotide polymorphism (SNP) in coding and genomic sequences in chickpea (Cicer arietinum L.). Euphytica 2008, 162, 291-300.

57. Jaccoud, D.; Peng, K.; Feinstein, D.; Kilian, A. Diversity arrays: A solid state technology for sequence information independent genotyping. Nucleic Acids Res. 2001, 29, E25.

58. Hearnden, P.R.; Eckermann, P.J.; McMichael, G.L.; Hayden, M.J.; Eglinton, J.K.; Chalmers, K.J. A genetic map of 1,000 SSR and DArT markers in a wide barley cross. Theor. Appl. Genet. 2007, 115, 383-391.

59. Peleg, Z.; Saranga, Y.; Suprunova, T.; Ronin, Y.; Röder, M.S. High-density genetic map of durum wheat $\times$ wild emmer wheat based on SSR and DArT markers. Theor. Appl. Genet. 2008, 117, 103-115.

60. Supriya, A.; Senthilvel, S.; Nepolean, T.; Eshwar, K.; Rajaram, V.; Shaw, R.; Hash, C.T.; Kilian, A.; Yadav, R.C.; Narasu, M.L. Development of a molecular linkage map of pearl millet integrating DArT and SSR markers. Theor. Appl. Genet. 2011, 123, 239-250.

61. Xia, L.; Peng, K.; Yang, S.; Wenzl, P.; de Vicente, M.C.; Fregene, M.; Kilian, A. DArT for high throughout genotyping of cassava (Manihot esculenta) and its wild relatives. Theor. Appl. Genet. 2005, 110, 1092-1098. 
62. Mace, E.S.; Xia, L.; Jordan, D.R.; Halloran, K.; Parh, D.K.; Huttner, E.; Wenzl, P.; Kilian, A. DArT markers: Diversity analyses and mapping in Sorghum bicolor. BMC Genomics. 2008, 9, 26.

63. Winter, P.; Benko-Iseppon, A.M.; Hüttel, B.; Ratnaparkhe, M.; Tullu, A.; Sonnante, G.; Pfaff, T.; Tekeoglu, M.; Santra, D.; Sant, V.J.; Rajesh, P.N.; Kahl, G.; Muehlbauer, F.J. A linkage map of the chickpea (Cicer arietinum L.) genome based on the recombinant inbred lines from a C. arietinum $\times$ C. reticulatum cross: Localization of resistance genes for Fusarium races 4 and 5 . Theor. Appl. Genet. 2000, 101, 1155-1163.

64. Choi, H.K.; Kim, D.; Uhm, T.; Limpens, E.; Lim, H.; Mun, J.H.; Kalo, P.; Penmetsa, R.V.; Seres, A.; Kulikova, O.; et al. A sequence-based genetic map of Medicago truncatula and comparison of marker colinearity with M. sativa. Genetics 2004, 166, 1463-1502.

65. Stein, N.; Prasad, M.; Scholz, U.; Thiel, T.; Zhang, H.; Wolf, M.; Kota, R.; Varshney, R.K.; Perovic, D.; Grosse, I.; Graner, A. A 1,000-loci transcript map of the barley genome: New anchoring points for integrative grass genomics. Theor. Appl. Genet. 2007, 114, 823-839.

66. Cho, S.; Kumar, J.; Shultz, J.F.; Anupama, K.; Tefera, F.; Muehlbauer, F.J. Mapping genes for double podding and other morphological traits in chickpea. Euphytica 2002, 125, 285-292.

67. Flandez-Galvez, H.; Ades, P.K.; Ford, R.; Pang, E.C.K.; Taylor, P.W.J. QTL analysis for ascochyta blight resistance in an intraspecific population of chickpea (Cicer arietinum L.). Theor. Appl. Genet. 2003, 107, 1257-1265.

68. Cobos, M.J.; Fernandez, M.; Rubio, J.; Kharrat, M.; Moreno, M.T.; Gil, J.; Millan, T. A linkage map of chickpea (Cicer arietinum L.) based on populations from Kabuli $\times$ Desi crosses: Location of genes for resistance to Fusarium wilt race 0. Theor. Appl. Genet. 2005, 110, 1347-1353.

69. Radhika, P.; Gowda, S.J.M.; Kadoo, N.Y.; Mhase, L.B.; Jamadagni, B.M.; Sainani, M.N.; Chandra, S.; Gupta, V.S. Development of an integrated intraspecific map of chickpea (Cicer arietinum L.) using two recombinant inbred line populations. Theor. Appl. Genet. 2007, 115, 209-216.

70. Anuradha, C.; Gaur, P.M.; Pande, S.; Gali, K.K.; Ganesh, M.; Kumar, J.; Varshney, R.K. Mapping QTL for resistance to botrytis grey mould in chickpea. Euphytica 2011, 182, 1-9.

71. Millán, T.; Winter, P.; Jungling, R.; Gil, J.; Rubio, J.; Cho, S.; Cobos, M.J.; Iruela, M.; Rajesh, P.N.; Tekeoglu, M.; et al. A consensus genetic map of chickpea (Cicer arietinum L.) based on 10 mapping populations. Euphytica 2010, 175, 175-189.

72. Santra, D.K.; Tekeoglu, M.; Ratnaparkhe, M.; Kaiser, W.J.; Muehlbauer, F.J. Identification and mapping of QTLs conferring resistance to ascochyta blight in chickpea. Crop Sci. 2000, 40, 1606-1612.

73. Cho, S.H.; Chen, W.D.; Muehlbauer, F.J. Pathotype-specific genetic factors in chickpea (Cicer arietinum L.) for quantitative resistance to Aschochyta blight. Theor. Appl. Genet. 2004, 109, 733-739.

74. Collard, B.C.Y.; Pang, E.C.K.; Ades, P.K.; Taylor, P.W.J. Preliminary investigations of QTL associated with seedlings resistance to Ascochyta blight from Cicer echinospermum, a wild relative of chick pea. Theor. Appl. Genet. 2003, 107, 719-729.

75. Tekeoglu, M.; Rajesh, P.N.; Muehlbauer, F.J. Integration of sequence tagged microsatellite sites to the chickpea genetic map. Theor. Appl. Genet. 2002, 105, 847-854. 
76. Rakshit, S.; Winter, P.; Tekeoglu, M.; Juarez Muñoz, J.; Pfaff, T.; Benko-Iseppon, A.M.; Muehlbauer, F.J.; Kahl, G. DAF marker tightly linked to a major locus for ascochyta blight resistance in chickpea (Cicer arietinum L.) Euphytica 2003, 132, 23-30.

77. Udupa, S.M.; Baum, M. Genetic dissection of pathotype-specific resistance to ascochyta blight disease in chickpea (Cicer arietinum L.) using microsatellite markers. Theor. Appl. Genet. 2003, 106, 1196-1202.

78. Iruela, M.; Castro, P.; Rubio, J.; Cubero, J.I.; Jacinto, C.; Millan, T.; Gil, J. Validation of a QTL for resistance to Ascochyta blight linked to resistance to Fusarium wilt race 5 in chickpea (Cicer arietinum L.). Eur. J. Plant Path. 2007, 199, 29-37.

79. Iruela, M.; Rubio, J.; Barro, F.; Cubero, J.I.; Millan, T.; Gil, J. Detection of two quantitative trait loci for resistance to Ascochyta blight in an intra-specific cross of chickpea (Cicer arietinum L.): development of SCAR markers associated with resistance. Theor. Appl. Genet. 2006, 112, 278-287.

80. Millán, T.; Rubio, J.; Iruela, M.; Daly, K.; Cubero, J.I.; Gil, J. Markers associated with Ascochyta blight resistance in chickpea and their potential in marker-assisted selection. Field Crops Res. 2003, 84, 373-384.

81. Cobos, M.J.; Rubio, J.; Strange, R.N.; Moreno, M.T.; Gil, J.; Millan, T. A new QTL for Ascochyta blight resistance in an RIL population derived from an interspecific cross in chickpea. Euphytica 2006, 149, 105-111.

82. Anbessa, Y.; Taran, B.; Warkentin, T.D.; Tullu, A.; Vandenberg, A. Genetic analyses and conservation of QTL for ascochyta blight resistance in chickpea (Cicer arietinum L.). Theor. Appl. Genet. 2009, 119, 757-765.

83. Aryamanesh, N.; Nelson, M.N.; Yan, G.; Clarke, H.J.; Siddique, K.H.M. Mapping a major gene for growth habit and QTLs for ascochyta blight resistance and flowering time in a population between chickpea and Cicer reticulatum. Euphytica 2010, 173, 307-319.

84. Sharma, K.D.; Winter, P.; Kahl, G.; Muehlbauer, F.J. Molecular mapping of Fusarium oxysporum f. sp. ciceris race 3 resistance gene in chickpea. Theor. Appl. Genet. 2004, 108, 1243-1248.

85. Madrid, E.; Rubiales, D.; Moral, A.; Moreno, M.T.; Millan, T.; Gil, J.; Rubio, J. Mechanism and molecular markers associated with rust resistance in a chickpea interspecific cross (Cicer arietinum $\times$ Cicer reticulatum). Eur. J. Plant Path. 2008, 121, 45-53.

86. Hossain, S.; Ford, R.; McNeil, D.; Pittock, C.; Panozzo, J.F. Inheritance of seed size in chickpea (Cicer arietinum L.) and identification of QTL based on 100-seed weight and seed size index. Aust. J. Crop Sci. 2010, 4, 126-135.

87. Cobos, M.J.; Rubio, J.; Fernandez-Romero, M.D.; Garza, R.; Moreno, M.T.; Millan, T.; Gil, J. Genetic analysis of seed size, yield and days to flowering in a chickpea recombinent inbred line population derived from a kabuli $\times$ desi cross. Ann. Appl. Biol. 2007, 151, 33-42.

88. Cobos, M.J.; Winter, P.; Kharrat, M.; Cubero, J.I.; Gil, J.; Millan, T.; Rubio, J. Genetic analysis of Agronomic traits in a wide cross of chickpea. Field Crops Res. 2009, 111,130-136.

89. Vadez, V.; Krishnamurthy, L.; Thudi, M.; Anuradha, C.; Colmer, T.; Turner, N.; Siddique, K.; Gaur, P.; Varshney, R.K. Assessment of ICCV $2 \times$ JG 62 chickpea progenies shows sensitivity of reproduction to salt stress and reveals QTL for seed yield and yield components. Mol. Breed. 2012, 30, 9-21. 
90. Rajesh, P.N.; Tullu, A.; Gil, J.; Gupta, V.S.; Ranjekar, P.K.; Muehlbauer, F.J. Identification of an STMS marker for the double-podding gene in chickpea. Theor. Appl. Genet. 2002, 105, 604-607.

91. Lichtenzveig, J.; Bonfil, D.J.; Zhang, H.B.; Shtienberg, D.; Abbo, S. Mapping quantitative trait loci in chickpea associated with time to flowering and resistance to Didymella rabiei the causal agent of ascochyta blight. Theor. Appl. Genet. 2006, 113, 1357-1369.

92. Abbo, S.; Molina, C.; Jungmann, R.; Grusak, M.A.; Berkovitch, Z.; Reifen, R.; Kahl, G.; Winter, P.; Reifen, R. Quantitative trait loci governing carotenoid concentration and weight in seeds of chickpea (Cicer arietinum L.). Theor. Appl. Genet. 2005, 111, 185-195.

93. Rajesh, P.N.; Coyne, C.; Meksem, K.; Sharma, K.D.; Gupta, V.; Muehlbauer, F.J. Construction of a HindIII Bacterial Artificial Chromosome library and its use in identification of clones associated with disease resistance in chickpea. Theor. Appl. Genet. 2004, 108, 663-669.

94. Ren, C.; Xu, Z.Y.; Sun, S.; Lee, M.-K.; Wu, C.; Zhang, H.-B. Genomic Libraries for Physical Mapping. In Handbook of Plant Genome Mapping: Genetic and Physical Mapping; Meksem, K., Kahl, G., Eds.; Wiley-VCH: Weinheim, Germany, 2004.

95. Wu, C.; Xu, Z.; Zhang, H.-B. DNA Libraries. In Encyclopedia of Molecular Cell Biology and Molecular Medicine, 2nd ed.; Meyers, R.A., Ed.; Wiley-VCH: Weinheim, Germany, 2004; Volume 3, pp. 385-425.

96. Wu, C.; Nimmakayala, P.; Santos, F.A.; Springman, R.; Tao, Q.; Meksem, K.; Lightfoot, D.A.; Zhang, H.-B. Construction and characterization of a soybean bacterial artificial chromosome library and use of multiple complementary libraries for genome physical mapping. Theor. Appl. Genet. 2004, 109, 1041-1050.

97. Zhang, X.; Scheuring, C.F.; Zhang, M.; Dong, J.J.; Zhang, Y.; Huang, J.J.; Lee, M-K.; Abbo, S.; Sherman, A.; Shtienberg, D.; Chen, W.; Muehlbauer, F.; Zhang, H-B. A BAC/BIBAC-based physical map of chickpea, Cicer arietinum L. BMC Genomics. 2010, 11, 501.

98. Zatloukalová, P.; Hřibová, E.; Kubaláková, M.; Suchánková, P.; Šimková, H.; Adoración, C.; Kahl, G.; Millán, T.; Doležel, J. Integration of genetic and physical maps of the chickpea (Cicer arietinum L.) genome using flow-sorted chromosomes. Chromosome Res. 2011, 19, 729-739.

99. Berkman, P.J.; Skarshewski, A.; Lorenc, M.T.; Lai, K.; Duran, C.; Ling, E.Y.S.; Stiller, J.; Smits, L.; Imelfort, M.; Manoli, S.; et al. Sequencing and assembly of low copy and genic regions of isolated Triticum aestivum chromosome arm 7DS. Plant Biotechnol. 2011, 9, 768-775.

100. Wicker, T.; Mayer, K.F.X.; Gundlach, H.; Martis, M.; Steuernagel, B.; Scholz, U.; Šimková, H.; Kubaláková, M.; Choulet, F.; Taudien, S.; Platzer, M.; Feuillet, C.; Fahima, T.; Budak, H.; Doležel, J.; Keller, B.; Stein, N. Frequent gene movement and pseudogene evolution is common to the large and complex genomes of wheat, barley, and their relatives. Plant Cell 2011, 23, $1706-1718$.

101. Mayer, K.F.X.; Martis, M.; Hedley, P.E.; Šimková, H.; Liu, H.; Morris, J.A.; Steuernagel, B.; Taudien, S.; Roessner, S.; Gundlach, H.; et al. Unlocking the barley genome by chromosomal and comparative genomics. Plant Cell 2011, 23, 1249-1263.

102. Mayer, K.F.X.; Taudien, S.; Martis, M.; Šimková, H.; Suchánková, P.; Gundlach, H.; Wicker, T.; Petzold, A.; Felder, M.; Steuernagel, B.; et al. Gene content and virtual gene order of barley chromosome 1H. Plant Physiol. 2009, 151, 496-505. 
103. Collard, B.C.Y.; Mackill, D.J. Marker-assisted selection: an approach for precision plant breeding in the twenty-first century. Philos. Trans. R. Soc. B 2008, 363, 557-572.

104. Moose, S.; Mumm, R.H. Molecular plant breeding as the foundation for 21 st century crop improvement. Plant Physiol. 2008, 147, 969-977.

105. Ribaut, J.M.; de Vicente, M.C.; Delannay, X. Molecular breeding in developing countries: Challenges and perspectives. Curr. Opin. Plant Biol. 2010, 13, 1-6.

106. Hospital, F.; Charcosset, A. Marker assisted introgression of quantitative trait loci. Genetics 1997, 147, 1469-1485.

107. Frisch, M.; Bohn, M.; Melchinger, A.E. Minimum sample size and optimal positioning of flanking markers in marker assisted backcrossing for transfer of a target gene. Crop Sci. 1999, 39, 967-975.

108. Ribaut, J.M.; Hoisington, D. Marker-assisted selection: New tools and strategies. Trends Plant Sci. 1998, 3, 236-239.

109. Salina, E.; Dobrovolskaya, O.; Efremova, T.; Leonova, I.; Roder, M.S. Microsatellite monitoring of recombination around the $V r n-B 1$ locus of wheat during early backcross breeding. Plant Breed. 2003, 122, 116-119.

110. Hospital, F. Selection in backcross programmes. Philos. Trans. R. Soc. B 2005, 360, 1503-1511.

111. Zamir, D. Improving plant breeding with exotic genetic libraries. Nature Rev. Genet. 2001, 2 , 983-989.

112. Zhang, X.; Zhou, S.; Fu, Y.; Su, Z.; Wang, X.; Sun, C. Identification of a drought tolerant introgression line derived from Dongxiang common wild rice (O. rufipogon Griff.). Plant Mol. Biol. 2006, 62, 247-259.

113. Rangel, P.N.; Brondani, R.P.; Rangel, P.H.; Brondani, C. Agronomic and molecular characterization of introgression lines from the interspecific cross Oryza sativa (BG90-2) $\times$ Oryza glumaepatula (RS-16). Genet. Mol. Res. 2008, 7, 184-195.

114. Gutiérrez, A.G.; Carabalí, S.J.; Giraldo, O.X.; Martínez, C.P.; Correa, F.; Prado, G.; Tohme, J.; Lorieux, M. Identification of a rice stripe necrosis virus resistance locus and yield component QTLs using Oryza sativa $\times$ O. glaberrima introgression lines. BMC Plant Biol. 2010, 10, 6 .

115. Eshed, Y.; Zamir, D. An introgression line population of Lycopersicon pennellii in the cultivated tomato enables the identification and fine mapping of yield-associated QTL. Genetics 1995, 141, 1147-1162.

116. Kamenetzky, L.; Asís, R.; Bassi, S.; de Godoy, F.; Bermúdez, L.; Fernie, A.R.; Sluys, M.A.V.; Vrebalov, J.; Giovannoni, J.J.; Rossi, M.; et al. Genomic analysis of wild tomato introgressions determining metabolism- and yield-associated traits. Plant Physiol. 2010, 152, 1772-1786.

117. Concibido, V.C.; La Vallee, B.; Mclaird, P.; Pineda, N.; Meyer, J.; Hummel, L.; Yang, J.; Wu, $\mathrm{K}$.; Delannay, X. Introgression of a quantitative trait locus for yield from Glycine soja into commercial soybean cultivars. Theor. Appl. Genet. 2003, 106, 575-582.

118. Foncéka, D.; Hodo-Abalo, T.; Rivallan, R.; Faye, I.; Sall, M.N.; Ndoye, O.; Fávero, A.P.; Bertioli, D.J.; Glaszmann, J.C.; Courtois, B.; et al. Genetic mapping of wild introgressions into cultivated peanut: A way toward enlarging the genetic basis of a recent allotetraploid. BMC Plant Biol. 2009, 9, 103. 
119. Tanksley, S.D.; Nelson, J.C. Advanced backcross QTL analysis: a method of the simultaneous discovery and transfer of valuable QTLs from unadapted germplasm into elite breeding lines. Theor. Appl. Genet. 1996, 92, 191-203.

120. McCouch, S.; Sweeney, M.; Li, J.; Jiang, H.; Thomson, M.; Septiningsih, E.; Edwards, J.; Moncada, P.; Xiao, J.; Garris, A. Through the genetic bottleneck: O. rufipogon as a source of trait-enhancing alleles for O. sativa. Euphytica 2007, 154, 317-339.

121. Naz, A.A.; Kunert, A.; Lind, V.; Pillen, K.; Léon, J. AB-QTL analysis in winter wheat: II. Genetic analysis of seedling and field resistance against leaf rust in a wheat advanced backcross population. Theor. Appl. Genet. 2008, 116, 1095-1104.

122. Blair, M.W.; Astudillo, C.; Restrepo, J.; Bravo, L.C.; Villada, D.; Beebe, S.E. Análisis multi-locacional de líneas de fríjol arbustivo con alto contenido de hierro en el departamento de Nariño. Fitotec. Colomb. 2005, 5, 20-27.

123. Chaky, J.M.; Specht, J.E.; Cregan, P.B. Advanced backcross QTL analysis in a mating between Glycine max and Glycine soja. In Proceedings of the Plant and Animal Genome XII Conference Abstracts, San Diego, CA, USA, 10-14 January 2004; pp. 545

124. Stam, P. Marker-Assisted Breeding. In Proceedings of the IX Meeting of EUCARPIA Section on Biometrics in Plant Breeding, Wageningen, the Netherlands, 1994; pp. 32-44.

125. Gupta, P.K.; Kumar, J.; Mir, R.R.; Kumar, A. Marker assisted selection as a component of conventional plant breeding. Plant Breed. Rev. 2010, 33, 145-217.

126. Gupta, P.K.; Langridge, P.; Mir, R.R. Marker-assisted wheat breeding: present status and future possibilities. Mol. Breed. 2010, 26, 145-161.

127. Tester, M.; Langridge, P. Breeding technologies to increase crop production in a changing world. Science 2010, 327, 818-822.

128. Bernardo, R.; Charcosset, A. Usefulness of gene information in marker-assisted recurrent selection: A simulation appraisal. Crop Sci. 2006, 46, 614-621.

129. Mayor, P.J.; Bernardo, R. Genome wide selection and marker-assisted recurrent selection in doubled haploid versus $F_{2}$ populations. Crop Sci. 2009, 49, 1719-1725.

130. Charcosset, A.; Moreau, L. Use of molecular markers for the development of new cultivars and the evaluation of genetic diversity. Euphytica 2004, 137, 81-94.

131. Meuwissen, T.H.E.; Hayes, B.J.; Goddard, M.E. Prediction of total genetic value using genome-wide dense marker maps. Genetics 2001, 157, 1819-1829.

132. Bernardo, R.; Yu, J. Prospects for genome-wide selection for quantitative traits in maize.Crop Sci. 2007, 47, 1082-1090.

133. Heffner, E.L.; Sorrells, M.E.; Jannink, J.L. Genomic selection for crop improvement. Crop Sci. 2009, 49, 1-12.

134. Jannink, J.L.; Lorenz, A.J.; Iwata, H. Genomic selection in plant breeding: from theory to practice. Brief. Funct. Genomics Proteom. 2010, 9, 166-177.

135. Robinson, G.K. That BLUP is a good thing: The estimation of random effects. Stat. Sci. 1991, 6, 15-32.

136. Streeck, T.S.; Piepho, H.P. Genome-wide selection by mixed model ridge regression and extensions based on geo statistical models. BMC Proc. 2010, 4, S1-S8. 
137. Bernardo, R. Genome wide selection with minimal selection in self-pollinated crops. Crop Sci. 2010, 50, 624-627.

138. Bernardo, R. Potential and practicality of genome wide selection in plants. In Proceedings of the Plant \& Animal Genomes XVIII Conference, San Diego, CA, USA, 9-13 January 2010.

(C) 2012 by the authors; licensee MDPI, Basel, Switzerland. This article is an open access article distributed under the terms and conditions of the Creative Commons Attribution license (http://creativecommons.org/licenses/by/3.0/). 